\title{
Antimicrobial activity and phytochemical profile from the roots of Lippia alba (Mill.) N.E. Brown
}

\author{
Jose G. Sena Filho ${ }^{1 *}$, Janaina G.S. Melor ${ }^{1}$ Antônio M. Saraiva ${ }^{2}$, Ademário M. Gonçalves ${ }^{2}$, \\ Maria Nelly Caetano Psiottano ${ }^{2}$, Haroudo S. Xavier ${ }^{1}$ \\ ${ }^{1}$ Laboratório de Farmacognosia, Departamento de Ciências Farmacêuticas, Universidade Federal de Pernambuco, \\ 50740-521, Recife, PE, Brazil, \\ ${ }^{2}$ Laboratório de Análises Microbiológicas, Departamento de Ciências Farmacêuticas, Universidade Federal de \\ Pernambuco, 50740-52,1 Recife, PE, Brazil
}

\begin{abstract}
RESUMO: “Atividade antimicrobiana e perfil fitoquímico das raízes de Lippia alba (Mill.) N.E. Brown”. Lippia alba (Mill.) N.E. Brown (Verbenaceae) é geralmente usada na medicina popular brasileira para o tratamento de doenças gástricas, febre, asma e como tranqüilizante. Este trabalho avaliou a atividade antimicrobiana dos extratos acetato de etila, metanol e aquoso das raízes de $L$. alba usando métodos de difusão em poços e o perfil fitoquímico. Os resultados obtidos mostraram que os extratos acetato de etila e metanol apresentaram atividade antimicrobiana contra Staphylococcus aureus (ATCC 6538P), Staphylococcus aureus (ATCC 6538) e Klebsiella pneumonia (ATCC 10031). Terpenóides, fenilpropanóides e açúcares foram detectados na análise fitoquímica.
\end{abstract}

Unitermos: Lippia alba, Verbenaceae, atividade antimicrobiana, análise fitoquímica.

\begin{abstract}
Lippia alba (Mill.) N.E. Brown (Verbenaceae) is commonly used in the Brazilian folk medicine to the treatment of gastric illnesses, diarrhea, fever, asthma, and as a tranquilizer. This work evaluated the antimicrobial activity of ethyl acetate, methanol and aqueous extracts from the roots of the L. alba using plates-holes diffusion assay and the phytochemical profile. The results obtained showed that the ethyl acetate and methanol extracts presented antimicrobial activity against Staphylococcus aureus (ATCC 6538P), Staphylococcus aureus (ATCC 6538) and Klebsiella pneumonia (ATCC 10031). Terpenoids, phenylpropanoids and sugars were detected in the phytochemical analysis.
\end{abstract}

Keywords: Lippia alba, Verbenaceae, antimicrobial activity, phytochemical analysis.

\section{INTRODUCTION}

Long before mankind discovered the existence of microbes, the idea that certain plants had healing potential, indeed, that they contained what we would currently characterize as antimicrobial principles, was well accepted. Since antiquity, man has used plants to treat common infectious diseases and some of these traditional medicine are still included as part of the habitual treatment of various maladies (Heinrich et al., 2004; Ríos et al., 2005).

Lippia alba (Mill.) N.E. Brown, also known as Lippia geminata HBK or Lantana alba (Mill), is a shrub about $3 \mathrm{~m}$ tall that belongs to the Verbenaceae family (Stashenko et al., 2003). In the Brazilian traditional medicine it's vulgarly known as erva-cidreira, chá-dotabuleiro and salsa Limão (Braga, 1976; Matos, 1996). Its leaves are employed as infusion or decoction to the treatment of gastric illnesses, diarrhea, fever, asthma, cough and tranquillizing remedy (Matos, 1996; Tavares et al., 2005; Morais et al., 2005). Large variations have been observed in the composition of $L$. alba essential oil, depending on the part of the plant employed in the distillation, on the plant's state of development and on the geographic location, the characteristics of the soil, climate, and others local conditions (Alea et al., 1997; Stashenko et al., 2003; Tavares et al., 2005). GC analyses of essential oil from three chemotypes of $L$. alba revealed the predominance of monoterpene type compounds such as citral (55.1\%), $\beta$-myrcene (10.5\%), and limonene (1.5\%) (Matos, 1996; Julião et al., 2003). Few pharmacological studies have been done on the genus Lippia. Among these, the studies on the species Lippia multiflora, Lippia origanoides, Lippia sidoides, L. integrifolia, Lippia lacunosa, Lippia rotundifolia and Lippia alba (Pascual et al., 2001, Fauth et al., 2002; Oliveira et al., 2006; Leitão et al., 2006; Barbosa-Filho et al., 2006) are included. The essential oil of Lippia alba showed antimicrobial activity against gram positive microorganisms, in general, with minimum inhibitory concentration (MIC) between 0.31 $0.63 \mathrm{mg} / \mathrm{mL}$ (Alea et al., 1997).

Despite the popular use of $L$. alba as a medicinal plant, there are no data about the antimicrobial effect 
and phytochemical profile from the roots of this vegetal specimen. Thus, the interest of this plant is justifiable because of its potential medicinal value.

\section{MATERIAL AND METHODS}

\section{Microorganisms}

Seven microbial species taken from international collections were analyzed: Encherichia coli (ATCC 9723), Klebsiella pneumonia (ATCC 10031), Staphylococcus aureus (ATCC 6538), Staphylococcus aureus (ATCC 6538P), Enterococcus faecalis (ATCC 33186), Salmonela sp (ATCC 8387) and Pseudomonas aeruginosa (ATCC14502).

\section{Plant material}

The vegetal specimens was collected in Timbaúba ( $\left.7^{\circ} 35^{\prime} \mathrm{S} ; 35^{\circ} 22^{\prime} \mathrm{W}\right)$, State of Pernambuco, Brazil in January 2005. The plant was identified by Prof. Dr. Haroudo Sátiro Xavier. A voucher specimen was deposited under $n^{\circ} 1011$ at the Pharmacognosy Herbarium of the Federal University of Pernambuco State -Brazil.

\section{Crude extract preparation}

The air dried and powdered roots (62.76 g) of Lippia alba (Mill) N.E. Brown were extracted separately and exhaustively with increase polarity of ethyl acetate (EEA), methanol (EME) and distillated water (EAQ) successively at room temperature ( $48 \mathrm{~h}$ for each solvent). Solvents were evaporated at $50^{\circ} \mathrm{C}$ under reduced pressure affording the extracts coded as hexane extract (HE) 1.6\%, ethyl acetate extract (EAc) $1.44 \%$, methanol extract (MeE) 2.24\% and water extract (WE) 3.22\%.

\section{Phytochemical profile}

The chromatographic analyses were made by TLC on Si gel (MERCK-Germany, 105553) developed by different solvent systems: EtOAc- $\mathrm{HCOOH}-\mathrm{AcOH}-\mathrm{H}_{2} \mathrm{O}$ (100: $11: 11: 26, \mathrm{v}: \mathrm{v})$, EtOAc-HCOOH-AcOH- ${ }_{2} \mathrm{O}$ (100: $0.5: 0.5: 0.5, \mathrm{v}: \mathrm{v}), \mathrm{Et}_{2} \mathrm{O}$-toluene-AcOH $10 \%$ (50 : $50: 50, \mathrm{v}: \mathrm{v})$. Toluene-AcOEt $(97: 3 \mathrm{v} / \mathrm{v})$, n-BuOH$\mathrm{Me}_{2} \mathrm{CO}$-Buffer Phosphate $\mathrm{pH}=5.0(40: 50: 10 \mathrm{v} / \mathrm{v})$

Table 1. Antimicrobial activities of the ethyl acetate, methanol and aqueous extracts of Lippia alba.

\begin{tabular}{|c|c|c|c|c|c|c|c|}
\hline \multirow[t]{3}{*}{ Microorganism } & \multirow{2}{*}{\multicolumn{2}{|c|}{$\begin{array}{c}\text { Extracts } \\
\text { EEA }\end{array}$}} & \multirow{2}{*}{\multicolumn{2}{|c|}{$\frac{(\mathrm{mg} / \mathrm{mL})}{\mathrm{EME}}$}} & \multirow{2}{*}{\multicolumn{2}{|c|}{ EAQ }} & \multirow{3}{*}{$\begin{array}{l}\text { Positive controls } \\
\text { Tetracycline }\end{array}$} \\
\hline & & & & & & & \\
\hline & 50 & 100 & 50 & 100 & 50 & 100 & \\
\hline $\begin{array}{l}\text { Encherichia coli } \\
\text { (ATCC 9723) }\end{array}$ & - & - & - & - & - & - & 25 \\
\hline Klebsiela pneumonia & & & & & & & \\
\hline (ATCC 10031) & - & 12 & - & - & - & - & 25 \\
\hline $\begin{array}{c}\text { Staphylococcus aureus } \\
\text { (ATCC 6538) }\end{array}$ & 11 & 13 & - & 12 & - & - & 25 \\
\hline Staphylococcus aureus & & & & & & & \\
\hline (ATCC 6538P) & 12 & 13 & - & 13 & - & - & 25 \\
\hline Enterococus faecalis & & & & & & & \\
\hline (ATCC 33186) & - & - & - & - & - & - & 28 \\
\hline (ATCC 8387) & - & - & - & - & - & - & 23 \\
\hline $\begin{array}{c}\text { Pseudomonas } \\
\text { aeruginosa } \\
\text { (ATCC14502) }\end{array}$ & NT & NT & NT & NT & - & - & 19 \\
\hline
\end{tabular}

Diameter of zone (mm), (-) negative; NT: not tested

Table 2. Minimum inhibitory concentration (MIC) exhibited by the EAA and EME.

\begin{tabular}{ccc}
\hline Microorganism & MIC & $(\mathrm{mg} / \mathrm{mL})$ \\
Klebsiela pneumonia (ATCC 10031) & $>2$ & $>2$ \\
\cline { 2 - 3 } Staphylococcus aureus (ATCC 6538) & 0,5 & 2 \\
Staphylococcus aureus (ATCC 6538P) & 1 \\
\hline
\end{tabular}


Table 3. Chromatography condition of phytochemistry screening.

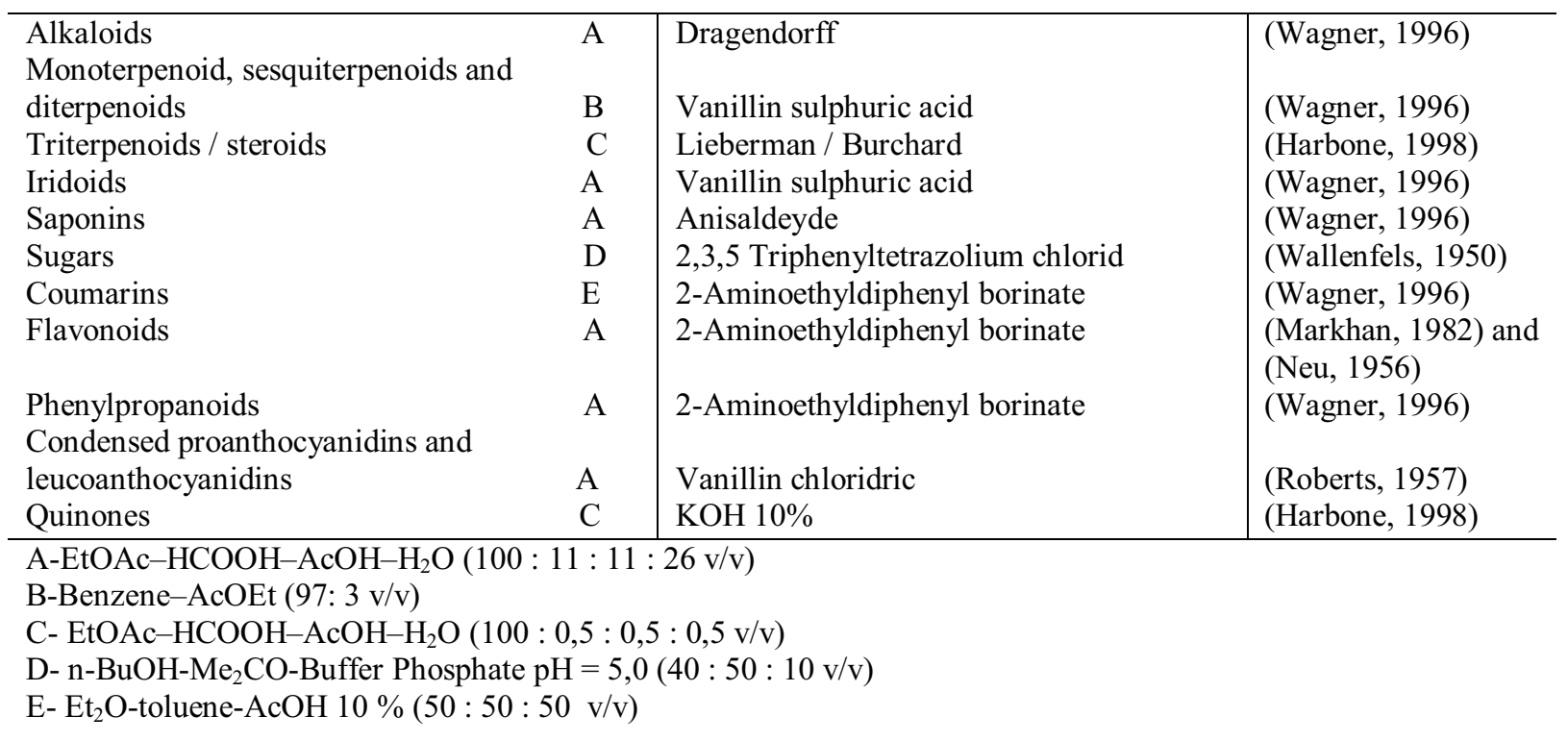

It was verified the presence or absence of terpenoids, steroids , saponins, sugars, flavonoids, phenylpropanoids, alkaloids, coumarins, condensed proanthocyanidins, leucoanthocyanidins and quinones (See Table 3).

\section{Plate-hole diffusion assay}

The microorganism cultures were grown in Müller Hinton agar at $37^{\circ} \mathrm{C}$. After $18 \mathrm{~h}$ of growth, each microorganism culture, were dissolved in $\mathrm{NaCl} 0.9 \%$ solution sterile until a concentration of 0.5 at MacFarland scale, was inoculated on the surface of Müller Hinton (MH) agar plates $(100 \mu \mathrm{L})$. The methodology used was the plate-holes diffusion assay (Ieven et al, 1979; Caetano et al., 2002). The plates were incubated at $37^{\circ} \mathrm{C}$ for $24 \mathrm{~h}$; after this period, the zones of growth inhibition around the discs and the holes were measured.

Tetracycline was the positive control $(1 \mathrm{mg} / \mathrm{mL})$. All determinations were made in duplicate.

\section{Minimum inhibitory concentration (MIC)}

The concentrations of $0.031,0.062,0.125,0.25$, $0.5,1$ and $2 \mathrm{mg} / \mathrm{mL}$ by the EAA and EME were tested against the microorganisms: Klebsiella pneumonia (ATCC 10031), Staphylococcus aureus (ATCC 6538), Staphylococcus aureus (ATCC 6538P).

\section{RESULTS AND DISCUSSION}

A total of 7 microorganisms were tested and the results are summarized in Table 1, following by the Minimum inhibitory concentration in Table 2. The EAQ extract of $L$. alba did not show any activity.
As can be observed in Table 1, the EEA and EME possessed the antimicrobial activity against some microorganism tested. In the assays against microorganisms by plates-holes diffusion method, the zones obtained were between 11 to $13 \mathrm{~mm}$.

The EEA and EME extracts of $L$. alba were activity against Staphylococcus aureus (ATCC 6538P), Staphylococcus aureus (ATCC 6538) and Klebsiella pneumonia (ATCC 10031).

The MIC values obtained were ranged between 0.5 - $2 \mathrm{mg} / \mathrm{mL}$ (Table 2). The best results were observed for the EEA extract against Staphylococcus aureus (ATCC 6538).

The phytochemical profile from the roots of $L$. alba detected the presence of terpenoids, phenylpropanoids, and sugars. On the other hand, It wasn't verified the presence of coumarins, condensed proanthocyanidins, leucoanthocyanidins, saponins, flavonoids, alkaloids, steroids and quinones.

\section{REFERENCES}

Alea JAP, Ortega AG, Rosado A, Rodriguez M, Baluja R 1997. Composición y propiedades antibacterianas del aceite essencial de Lippia alba (Mill.) N.E. Brown. Rev Cubana Farm 30: 1-8.

Barbosa-Filho JM, Medeiros KCP, Diniz MFFM, Batista LM, Athayde-Filho PF, Silva MS, Cunha EVL, Almeida JRGS, Quintans-Júnior LJ 2006. Natural products inhibitors of the enzyme acetylcholinesterase. Rev Bras Farmacogn 16: 258-285.

Braga R 1976. Plantas do Nordeste, especialmente do Ceará. Fortaleza: Edição Mossoroeinse.

Caetano N, Saraiva A, Pereira R, Carvalho D, Pimentel MCB, Maia MBS 2002. Determinação de atividade antimicrobiana de extratos de plantas de uso popular 
como antiflamatório. Rev Bras Farmacogn 12: 132135.

Fauth S, Campos AR, Silveira ER, Rao VS 2002. Efeitos de óleos essenciais de plantas no tempo de sono induzido por cetamina em camundongos. Rev Bras Farmacogn 12 (Supl.): 112-113.

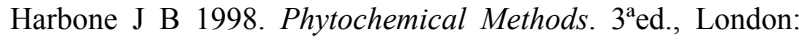
Chapman \& Hall.

Heinrich M, Barnes J, Gibbons S, Williamson E M 2004. Fundamental of Pharmacognosy and Phytotherapy. Churchill Livingstone, Edinbrugh.

Ieven M, Vanden Bergher DA, Mertens F, Vlietinck A, Lammens E 1979. Screening of higher plants for biological activities. Planta Med 36: 311-321.

Julião LS, Tavares ES, Lage CLS, Leitão SG 2003. Cromatografia em camada fina de extratos de três quimiotipos de Lippia alba (Mill.) N.E. Brown. (erva-cidreira), Rev Bras Farmacogn 13: 36-38.

Leitão SG, Castro O, Fonseca EM, Julião LS, Tavares ES, Leo RRT, Vieira RC, Oliveira DR, Leitão GG, Martino V, Sulsen V, Barbosa YAG, Pinheiro DPG, Silva PEA, Teixeira DF, Lourenço MCS 2006. Screening of Central and South American plant extracts for antimycobacterial activity by the Alamar Blue test. Rev Bras Farmacogn 16: 6-11.

Markhan KR 1982. Thecniques of flavonoid Identification. London:.Academic Press.

Matos FJA 1996. As ervas cidreiras do Nordeste do Brasil. Estudo de três quimiotipos de Lippia alba (Mill) N.E. Brown (Verbenaceae). Parte I Farmacognosia. Rev Bras Farm 72: 65-67.

Morais SM, Dantas JDP, Silva ARA, Magalhães EF 2005. Plantas medicinais usadas pelos índios Tapebas do Ceará. Rev Bras Farmacogn 15: 169-177.

Neu $\mathrm{R}$ 1956. A New reagent for differentiating and determining flavones of paper chromatograms. Naturswissenschaften 43: 82.

Oliveira RAG, Lima EO, Vieira WL, Freire KRL, Trajano VN, Lima, IO, Souza EL, Toledo MS, Silva-Filho RN 2006. Estudo da interferência de óleos essenciais sobre a atividade de alguns antibióticos usados na clínica. Rev Bras Farmacogn 16: 77-82.

Pascual ME, Slowing K. Carretero E, Sánchez-Mata D, Villar A 2001. Lippia: traditional uses, chemistry and pharmacology: a review. J Ethnopharmacol 76: 201214.

Ríos JL, Recio MC 2005. Medicinal plants and antimicrobial activity. J Ethnopharmacol 100: 80-84.

Roberts EAH, Cartwright RA, Oldschool M 1957. Phenolic substances of manufactured tea. I. Fractionation and paper chromatography of water-soluble substances. $J$ Sci Food Agr 8: 72-80.

Stashenko EE, Jaramillo BE, Martinez JR 2003. Comparison of different extraction methods for the analysis of volatile secondary metabolites of Lippia alba (Mill.) N.E. Brown, grown in Colombia, and evaluation of its in vitro antioxidant activity, $J$ Chromatogr A 1025: 93-103.

Tavares E.S, Julião LS, Lopes D, Bizzo HR, Lage CLS, Leitão SG 2005. Análise do óleo essencial de folhas de três quimiotipos de Lippia alba (Mill.) N.E.Br. (Verbenaceae) cultivados em condições semelhantes. Rev Bras Farmacogn 15: 1-5.
Wagner H, Bladt S 1996. Plant drug analysis - A thin layer chromatography atlas. Munich: Springer. $2^{\mathrm{a}} \mathrm{ed}$.

Wallenfels K 1950. Detection of reducing sugars in paper chromatogram and quantitative evaluation. Naturwissenschaften 37, 491-492. 